Article

\title{
The Search for Dog in Cervantes
}

\author{
Ivan Schneider
}

Seattle, WA 98104, USA; ivan@ivantohelpyou.com

Received: 20 March 2017; Accepted: 11 July 2017; Published: 14 July 2017

\begin{abstract}
This paper reconsiders the missing galgo from the first line in Don Quixote with a set of interlocking claims: first, that Cervantes initially established the groundwork for including a talking dog in Don Quixote; second, through improvisation Cervantes created a better Don Quixote by transplanting the idea for a talking dog to the Coloquio; and third, that Cervantes made oblique references to the concept of dogs having human intelligence within the novel.
\end{abstract}

Keywords: Cervantes; talking dogs; narratology; animal studies

\section{Introduction}

"[Cervantes] saw his scenes and the actors in them as pictures in his mind before he put them on paper, much as El Greco [see Figure 1] made little clay models of his figures before painting them." (Bell 1947, p. 101)

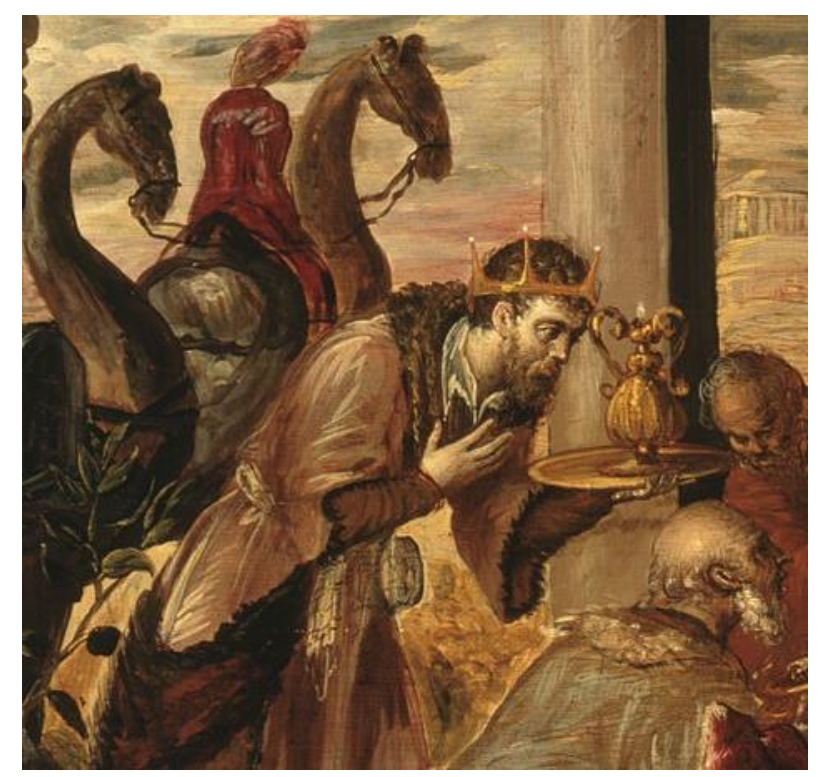

Figure 1. Detail from El Greco, Adoration of the Magi (1568), Museo Soumaya, Mexico City. Public domain (Greco 1568).

The knight-errant Don Quixote wears his armor, carries his lance, and rides his skinny steed Rocinante throughout the novel and in the popular imagination. But what happened to the greyhound, or galgo? Why does Cervantes mention a hidalgo's galgo at the start of the first chapter of Book I of Don Quixote, and why does he let it disappear?

This unexplained absence seems to be a clear violation of the dramatic principle of "Chekhov's Gun," i.e., "Don't put a loaded gun on stage if you don't plan to shoot it" (Chekhov 1976). In this case, 
the loaded gun is a fast greyhound, introduced alongside the most iconic items carried by the knight only to be relegated to being a mere detail on the level of a pot of stew.

The famous first line of the novel:

“In a village in La Mancha (I don't want to bother you with its name) there lived, not very long ago, one of those gentlemen who keep a lance in the lance-rack, an ancient shield, a skinny old horse, and a fast greyhound." (Cervantes 1999b, p. 13)

"En un lugar de la Mancha, de cuyo nombre no quiero acordarme, no ha mucho tiempo que vivía un hidalgo de los de lanza en astillero, adarga antigua, rocín flaco y galgo corredor." (Cervantes 1999a, pt 1 chp. 1)

Given its prominent placement, one might expect the greyhound to reappear elsewhere within the novel, as do Don Quixote's lance, shield, and horse. Any such expectation is confounded. Certainly, you would not expect a dog to appear in a book of chivalry, and nevertheless, in the very first sentence of a parody that, according to the Prologue," "tries to shatter the authority of all those tales of chivalry" (Cervantes 1999b, p. 11), we find a dog. Bahktin cites Don Quixote as an exemplar of parody (Bakhtin 1981, p. 51) and of the "novelistic hybrid" (Bakhtin 1981, p. 361) that mixes high and low, "dragging what is being compared [i.e., chivalric novels] down to the dregs of an everyday gross reality congealed in prose" (Bakhtin 1981, p. 386). In a parody, by any definition and of any genre, a dog would not be out of place.

The learned Cervantista knows full well that the galgo from the first line never reappears, but the first-time reader, expecting parody and immediately finding a dog, might anticipate a second appearance of the galgo for comic effect, or if nothing else, to mark the moment of separation between hound and hunter. These divergent expectations separating naïve from experienced readers illustrate reader-response theory and Iser's "active interweaving of anticipation and retrospection" (Iser 2007, p. 1006). On a first reading of Don Quixote, a person, particularly one attuned to the presence of literary animals (e.g., by a child or an animal narratologist), would anticipate eventual resolution on the question of the galgo; but even these readers would, in retrospect, relegate the detail to apparent meaninglessness upon the unfolding of the story. It is the project of this paper to revisit that overly hasty dismissal.

The English-language critical literature only lightly covers the topic of the galgo. Flores explains the missing galgo as a symbolic representation of the world of the past that Don Quixote is about to abandon: "Cervantes, who in his opening sentence is juggling with the past [ ... ], the present [...], and the future (the hidalgo, the lanza en astillero, the adarga antiqua, and the rocin flaco will transform later on into a knight, a fighting weapon, a protective shield, and Rocinante, respectively), can then and there both mention and dispense with the past of the hidalgo (the greyhound) with which the future knight will have nothing to do" (Flores 1993, pp. 212-13).

Beusterien looks at the actual encounters with galgos in the narrative, leaving out those times when characters merely refer to galgos metaphorically or in passing conversation. He writes:

"Generally, Cervantes was interested in dogs. He wrote 'El coloquio de los perros,' the most provocative dog dialogue ever written. The opening line of Don Quijote reminds the reader of one of the protagonist's former companions. Quijano has an old galgo corredor. When Quijote leaves on his first sally, he never mentions the dog again. Although at the end of his adventures Quijote does not return to that galgo that he left behind, the conclusion of Part II mentions his meeting with galgos. When Quijote reaches his

1 In the prologue to Part I, the author is interrupted while sitting at his desk: “ ... wondering what I ought to say, one of my friends suddenly came in, clever, smart, and seeing me so buried in thought asked me why, and I didn't hide anything from him ..." (Cervantes 1999b, p. 7). Nowhere does it say that this unnamed friend, who gains unbidden access to the writer's inner sanctum, was human. 
village and arrives home for good (to die), some greyhounds chase a rabbit right between the feet of Sancho's donkey." (Beusterien 2010, p. 101)

This paper reconsiders the missing galgo in Don Quixote with a set of interlocking claims: first, that Cervantes initially established the groundwork for including a talking dog in Don Quixote; second, through improvisation Cervantes created a better Don Quixote by transplanting the idea for a talking dog to the Coloquio; and third, that Cervantes made oblique references to the concept of dogs having human intelligence within the novel. These assertions synthesize readings in Cervantes scholarship combined with the burgeoning field of animal narratology at the intersection of narratology and animal studies.

In constructing an argument, I make some simplifying assumptions, the first being that the immediate disappearance of the galgo was intentional. In the words of Bruce Wardropper: "In judging a work of art the critic must assume first the relevance of every detail" (Wardropper 1957, p. 588). The alternative is that Cervantes carelessly neglected to tie up the loose end of a missing galgo throughout scores of ensuing chapters; that Homer nods. Such inadvertent forgetting would form the basis for an intriguing psychoanalytic reading based on the galgo, following Johnson's procedure for approaching the question of the unconscious in texts: "... to look for gaps in the discourse which reveal the presence of something concealed beneath the visible surface, or, in El Saffar's phrase, something left unsaid" (Johnson 1993, p. 82). What, then, would it mean for Cervantes to have concealed the presence of the hunting dog, a symbol of wealth and nobility, even while elevating to mythical status the worn-out nag Rocinante? If unintentional, such an erasure would speak volumes about Cervantes in relation to his society's perception of the utility of animals-and yet it is much more satisfying to consider the erasure an intentional move that reveals something left unsaid about Cervantes's artistry.

I also assume that the term galgo refers to a dog. Gregorio Martínez Navarro suggests that the various English translators have gotten it wrong all these years, that absent the indefinite article ("un"), "galgo corredor" is an adjectival phrase describing Rocinante rather than a noun phrase referring to what he calls a "ghost greyhound," or "galgo fantasma" (Navarro 2006). While this would be a tidy solution to the mystery of the disappearing dog, we will proceed according to the commonly accepted translation, that our hidalgo was one of those hidalgos with both horse and hound, not a hound-like horse. As none of the items inventoried are preceded by an indefinite article, this strongly suggests that each item should be given similar footing as idiomatic yet independent noun phrases.

My last preliminary assumption is that the dog was not simply a throwaway detail illustrating the hidalgo type. The phrase "one of those gentlemen" ("hidalgo de los de") suggests that many hidalgos, not just Alonso Quijano, possess shield and rack, horse and hound. These possessions and animals act as class and status markers, making the listed items useful to describe a typical member of the Spanish lesser nobility of hidalgo gentlemen. Given that three of those items persist as entities throughout the novel, it would be capricious to single out the galgo as disposable. We should start with the assumption of the animal's importance, and then seek explanations that illuminate the text in new ways.

The body of the paper includes a brief timeline of the inferred dates of composition for the later works of Cervantes, including Don Quixote and the Exemplary Novels; followed by three interlocking claims:

1. Cervantes established the groundwork for a talking dog in Don Quixote. Although dogs and beasts speak in Cervantes' later works, the genesis of the Cervantine talking animal can be found first in Don Quixote. This creates an expectation of animal intelligence throughout the work, and there are indications within the text that allow for the possibility of the galgo as being a witness to the archival history of Don Quixote.

2. Cervantes improvised a different way forward. Despite the early potential for a talking-dog interlocutor or narrator, there are, as we know, no overt talking dogs in Don Quixote. Instead of cultivating a talking-dog story within Don Quixote, Cervantes may have transplanted the concept 
to "The Colloquy of the Dogs," or "El coloquio de los perros" (hereafter the Coloquio). We can identify the precise moment when the galgo was written out of the story as Don Quixote's return from the first sally, when the housekeeper makes no mention of the galgo even while accounting for the remaining items of the opening quartet. Shortly thereafter, Sancho Panza was introduced, providing Don Quixote with a human interlocutor that could engage in rich dialogues with other human characters in a way that an animal companion could not.

3. Cervantes makes oblique references to anthropomorphic animal intelligence. The unusual phrase "greyhound of an author" (galgo de su autor") suggests an ironic nod to the discarded concept of a talking-dog narrator, prompting a review of Cervantes' narrative strategies. The further appearances of galgos in the novel have hunting-dog connotations, leading to Don Quixote's confrontation near the end of his life with galgos perceived to be wicked magicians. These galgos take on new resonance with consideration of the first two claims.

\section{Background}

Don Quixote was published in two parts: Part I in 1605, and Part II in 1615. In the interim, Cervantes compiled Exemplary Novels (Cervantes 2016), published in 1613. Exemplary Novels includes the Coloquio, a talking-dog story which El Saffar designates as one of those stories "comparable in greatness to Don Quixote itself." Furthermore, El Saffar places the composition of Coloquio, and the other highly-regarded stories, as having been "written around the time when Part I was composed, that is, between 1602 and 1606" (Saffar 1976, p. 11). This creates an intriguing picture of other manuscripts sharing the same desk as the First Part of Don Quixote, and the presence within Don Quixote of interpolated stories supports the timeline. For example, the three-chapter interpolated story El curioso impertinente, translated by Raffel as "The Story of the Man Who Couldn't Keep from Prying," has been the subject of a longstanding debate about whether it forms an essential part of Don Quixote, or if (per Boussagol via Wardropper) it's "a novela ejemplar which Cervantes published as part of his great novel because he had it on his hands" (Wardropper 1957, p. 587). Both points of view can be correct, in that Cervantes may indeed have had on his hands a fully formed idea for El curioso impertinente, and in deciding to interpolate it into Don Quixote, subsequently found ways to form thematic connections with the work as a whole.

Following the publication of Exemplary Novels in 1613, Cervantes' desk is no tidier than it had been ten years earlier. At that point, he has yet to release the Second Part of Don Quixote (Cervantes 1999b) and his collection of plays in Eight Interludes (Cervantes 1996) in 1615, and the posthumously-published Persiles and Sigismunda (Cervantes 2009) in 2017. In the Second Part of Don Quixote, Cervantes no longer interpolates the impertinences of the First Part, and the narrator explains that the Arab historian Cidi Hamete Benengali "had decided not to introduce any separate, artful tales, but only such narratives as, to his mind, emerged out of the strictly historical facts" (Cervantes 1999b, p. 586). Meanwhile, Persiles and Sigismunda is almost entirely built on a carefully-wrought framework of interpolated stories from secondary characters. Even though the titular characters remain at the center, their story is revealed only at the end of the novel. The narrative is built around the stories of the people they meet during their adventures, and in this sense, Persiles and Sigismunda is the highest expression of the Cervantean aesthetic of interpolation, bringing together a diversity of perspectives from a range of characters without apology for the interruptions. Cervantes wanted to tell stories from different perspectives, and in Persiles and Sigismunda he formed the appropriate vehicle to do so.

The interpolated story El curioso impertinente in Don Quixote could have been easily transplanted into Exemplary Novels, which implies that such transplantations occurred during the simultaneous creation of both works. The argument to follow suggests that the Coloquio was a transplanted seedling from Don Quixote that found more fertile ground for germination in the context of Exemplary Novels, and that (to continue the gardening analogy) some of the Coloquio's roots remained intact in Don Quixote's soil. 


\section{Can I Get a Witness?}

The history of the talking animal goes back at least to Aesop (see Ziolkowski 1983), and Carranza describes the influence of Aesop on Cervantes via the 15th century Life of Aesop published together with Aesop's Fables during Cervantes' lifetime (Carranza 2003, p. 148).

The most obvious example of a talking-animal story in Cervantes can be found in the final part of Exemplary Novels, the Coloquio, which gives voice to animals long desiring to transmit the contents of their prodigious memories; in the words of the talking dog Berganza: " . . ever since I had the strength to gnaw a bone I have wanted to speak, to say things that settled in my memory, and there, being old and numerous, either moldered away or were forgotten" (Cervantes 2016, p. 368). This places us in a fictional world in which dogs not only speak, but also yearn to share the wisdom of their experiences with others.

Cervantes' final work, Persiles and Sigismunda, contains talking wolves: "one of them ... I swear it's true ... told me with a clear and distinct voice and in my own language: 'Spaniard, go away and look elsewhere for your fate, unless you wish to die here torn apart by our claws and teeth; and don't ask who it is telling you this, just thank Heaven you've found mercy even among wild animals'" (Cervantes 2009, pp. 40-41).

Yet the first appearance of a talking animal within the works of Cervantes appeared in neither the Coloquio nor Persiles and Sigismunda, but rather in the commendatory verses in the front matter of Don Quixote. The poem "On Rocinante," by El Donoso, the Motley Poet, begins in the voice of the first-person animal:

I am that Rocinante fa-,

Great-grandson of great Babie-,

Who, all for being lean and bon-,

Had one Don Quixote for an own-;

But if I matched him well in weak-,

I never took short commons meek-,

But kept myself in corn by steal-,

A trick I learned from Lazaril-,

When with a piece of straw so neat-

The blind man of his wine he cheat-" (Cervantes 1999c)

Soy Rocinante, el famo-

bisnieto del gran Babie-.

Por pecados de flaque-,

fui a poder de un don Quijo-.

Parejas corrí a lo flo-;

mas, por uña de caba-,

no se me escapó ceba-;

que esto saqué a Lazari-

cuando, para hurtar el vi-

al ciego, le di la pa- (Cervantes 1999a)

In El Donoso's poem, Rocinante claims knowledge of his lineage back to Babieca, the legendary horse of the medieval warrior El Cid, and in learning the art of theft from a famous episode in La vida de Lazarillo de Tormes (1554), the horse also demonstrates a degree of cultural literacy. We also see the poetic device of a missing syllable at the end of each line, a recurring, anticipatory pause evoking the difficulty of human-animal communications. Then, in a commendatory sonnet from the poet Solisdán, Rocinante speaks with Babieca. In this final poem in the front matter, which Haley calls a "coloquio de los caballos" ("dialogue of the horses") (Haley 1984, p. 175), the horses speak in complete sentences, animal-to-animal: 
B. "How comes it, Rocinante, you're so lean?"

R. "I'm underfed, with overwork I'm worn."

B. "But what becomes of all the hay and corn?"

R. "My master gives me none; he's much too mean."

B. "Come, come, you show ill-breeding, sir, I ween;

"T is like an ass your master thus to scorn."

$\mathrm{R}$. He is an ass, will die an ass, an ass was born;

Why, he's in love; what's plainer to be seen?"

B. "To be in love is folly?"-R. "No great sense."

B. "You're metaphysical."-R. "From want of food."

B. "Rail at the squire, then."-R. "Why, what's the good?

I might indeed complain of him, I grant ye,

But, squire or master, where's the difference?

They're both as sorry hacks as Rocinante." (Cervantes 1999c)

B. ¿Cómo estáis, Rocinante, tan delgado?

$R$. Porque nunca se come, y se trabaja.

B. Pues, ¿qué es de la cebada y de la paja?

R. No me deja mi amo ni un bocado.

B. Andá, señor, que estáis muy mal criado,

pues vuestra lengua de asno al amo ultraja.

$R$. Asno se es de la cuna a la mortaja.

¿Queréislo ver? Miraldo enamorado.

B. ¿Es necedad amar? R. No es gran prudencia.

B. Metafísico estáis. R. Es que no como.

B. Quejaos del escudero. R. No es bastante.

¿Cómo me he de quejar en mi dolencia,

si el amo y escudero o mayordomo

son tan rocines como Rocinante? (Cervantes 1999a)

On the heels of this dialogue begins the first part of Don Quixote. Given the context of the commendatory verses of Cervantes' alter-egos El Donoso and Solisdán, we enter the main narrative of Don Quixote with the foreknowledge that through poetry, animals can not only communicate clearly with each other, but also haltingly with a human intermediary. From this, our expectation should be that the animals we encounter possess a humanlike intelligence. In Don Quixote, the desire to communicate across species boundaries can be found in both horse and human. In 1.15, the narrator states that "had [the badly-beaten Rocinante] possessed a tongue to complain with, most assuredly neither Sancho nor his master would have been behind him" (Cervantes 1999b, p. 86). Later, Sancho ruminates about his yearning for animals to speak "as they used to in Guisopete [Aesop]'s time," so that he might "tell my donkey anything I felt like, and that way I could live with my bad

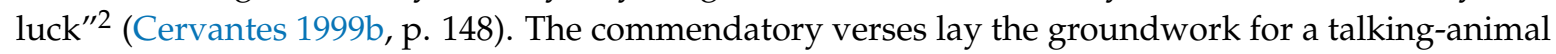
narrative, and yet the desires of both Sancho and Rocinante remain unfulfilled.

2 Ormsby translates the phrase "departiera yo con mi jumento" (Cervantes 1999c) as "I could talk to Rocinante [sic]," mistaking a donkey (jumento) for a horse. Raffel's translation identifies the correct animal, but the phrase "tell my donkey" connotes the animal's passive listening rather than the presence of an Aesopian dialogue partner. According to Covarrubias' 1611 dictionary, the primary meaning of the verb "departir" is "razonar, quando uno pregunta, y otro responde; pero quando uno se lo habla todo, no departe, por que no da parte" (Covarrubias Horozco 1611, p. 647), or "to reason, when one asks, and another responds; but when only one speaks, one does not departe, because one does not da parte ["give part," i.e. allow one's interlocutor to speak]" (translation mine). By this definition, and with his mangled Aesop reference, Sancho wished for an asinine dialogue. It may have been an unequal dialogue, as the following phrase "anything I felt like" ("lo que me viniera en gana") (Cervantes 1999c) indicates that Sancho was more interested in speaking his own mind than eliciting the donkey's perspective, but a dialogue nonetheless. 
Given these Aesopian traces, we should consider the animals we encounter as sentient beings with the latent ability to communicate in human language, and it is in this spirit that we further investigate the whereabouts of the missing hound. If the hidalgo Alonso Quijano indeed had a galgo of quiet intelligence, that galgo would have been present to observe the activities described in the early chapters. On that premise, we can revisit the opening chapters from the perspective of the canine to imagine what the galgo would have seen.

The imagined perspective of the galgo comes into play with the idea of Don Quixote as a history. Brian D. Patrick writes: "Don Quixote presents itself as a (fictive) work of history, and historians generally narrate events of which their knowledge is textually mediated rather than first hand [ ... ]" (Patrick 2008, p. 125). Yet history texts must originate in first-hand accounts. Human sources were present during Don Quixote's adventures with the introduction of Sancho Panza. But who was present to bear witness to Alonso Quijano's solitary ruminations and his subsequent transformation into Don Quixote?

At home, the hidalgo "lived with a housekeeper who was over forty, and a niece who hadn't reached twenty, plus a boy for the fields and the market" (Cervantes 1999b, p. 13). Presumably, they would have been able to provide some account of the madness of Uncle Alonso. But would the housekeeper have watched silently as Alonso polished up his great-grandfather's suit of armor, assembled a half-helmet, and tested its strength with a sword? Would the niece or the boy have observed the old man over the course of four days imagining names for his old horse, or for eight days while he thinks up his own title and name, or rehearsing his speech to Dulcinea del Toboso? The only one with the proximity, access, and sentience (per the laws of the Cervantine universe) to bear witness was none other than the galgo. In this parody of history, only the galgo could have testified as to the soliloquies and reveries of his master.

In the first sally, Cervantes adheres to the constraints of a story having a plausible canine narrator, carefully keeping Don Quixote within earshot of a watchful galgo. This suggests that Cervantes, as an improvisatory writer, initially toyed with the idea of a canine source for the historical account of a hidalgo-turned-knight.

The narrator uses an interesting turn of phrase when Don Quixote embarks upon his first sally:

“... without telling anyone what he was up to or being seen by a single soul ..."

(Cervantes 1999b, p. 17)

"Y así, sin dar parte a persona alguna de su intención, y sin que nadie le viese ... "

(Cervantes 1999a, pt 1 chp. 2)

The first part of the phrase states that "persona alguna," or "no person," was told of his departure, which stands in contrast with the second part of the phrase: "nadie le viese," or "no one saw him." This offers a pair of clever loopholes-since the galgo is not a persona, we can imagine Don Quixote revealing to his dog the details of his impending departure. Subsequently, even if the dog did not visually observe Don Quixote's departure, the dog may have yet borne witness using other senses.

Following Don Quixote's unseen departure, the galgo corredor would have had little trouble tracking him throughout his out-of-doors adventures of the first sally from Chapters 2 through 6 , including the visit to the inn; the knighthood ceremony in the stable and the fight with the muledrivers; Andrés being whipped by the farmer Juan Haldudo and the encounter with the Toledo merchants; Don Quixote's return home; and the inquisition of the library. A galgo would make a plausible and consistent witness for these events. Although the concept of dogs-as-pets is a relatively modern invention, in terms of the evolved bond between dogs and humans we are close enough to Cervantes' time to allow for the notion of a middle-aged man in his library forming a close bond with his dog, even one such as a galgo bred for hunting.

An objection may be raised-might the history have relied not on the galgo, but rather upon the testimony of the horse Rocinante? After all, the commendatory verses feature talking horses, not talking dogs. Also, Don Quixote asks the "noble chronicler of this extraordinary history" to 
"not forget my good Rocinante, unendingly the companion of all my wanderings and my every journey" (Cervantes 1999b, p. 18). Such constant companionship would have made Rocinante an excellent witness. Yet when it comes to the earlier transformation of Alonso Quijano, it strains credulity to expect that a horse would be given access to a gentleman's library or home. The text states that Alonso Quijano polished his great-grandfather's suit of armor prior to naming Rocinante (Cervantes 1999b, p. 15), which implies that the horse could not have witnessed this event, nor overheard Alonso's mutterings as inscribed in the novel.

Of course, we know full well that Cervantes did not, in fact, introduce a talking-dog narrator in Don Quixote. Don Quixote contains no interpolated story told by a talking dog, or by any talking animal. Before we mourn the loss of the galgo, we must identify where Cervantes may have turned away from the idea, how he did so, and what may have deterred him from taking this path.

\section{Gone Galgo}

Cervantes was an improviser. Roberto González Echevarría finds "a great deal of implicit improvisation" in Part I of Don Quixote, with "features of the novel itself that seem to betray their improvised construction" including several "notorious Cervantine oversights" (Echevarría 2015, p. 171). Ramón Menéndez Pidal writes that "Cervantes wanted the action to be fraught with all the trifling inconsistencies of improvisation" and that Cervantes "refuses to be bogged down by useless detail" (Pidal 2005, p. 76). Indeed, one might consider the entire question of the galgo to be a useless detail, which would be a reasonable inference were it not for the fact that Cervantes soon turned his pen to the talking-dog short story of the Coloquio. If we follow El Saffar's timeline, the Coloquio was written simultaneously with the composition of Don Quixote. Thus, the galgo must be considered a useful detail, and rather than to make a blanket assertion that the detail doesn't matter, we should use Cervantes' improvisatory skill to explain how the animal was erased.

An improvisatory writer would soon chafe at the limitations involved with the labyrinthine plotting needed to have a hidden canine narrator following the protagonist. The concept of a silent, watchful dog stalking Don Quixote quickly introduces logistical difficulties and irresolvable complexities. That is, how would a dog possibly follow the adventures of his companion without getting involved in the story? Would a faithful dog have watched silently as his master engaged in armed combat? At some point, the dog in the shadows would need to partake in the hunger, pain, and blanket-tossing. My hypothesis is that Cervantes found a better solution in Sancho Panza. It's much funnier to have Sancho tossed in a blanket than to subject a galgo to similar treatment. Then, we can surmise that Cervantes came up with a better solution for how to tell a talking dog story. Instead of having to choreograph the complex movements of a dog following a single master, he told the retrospective life story of a dog with several masters through a dialogue contained in the frame story of the Casamiento.

Given these better alternatives, we find Cervantes pulling a bit of sleight-of-hand to erase the galgo from the reader's memory. After the first sally, the farmer brings Don Quijote home to their village, where they hear the housekeeper "loudly proclaiming" to the priest and the barber: "He hasn't been seen in three days, and neither has his horse, or his shield, or his lance, or his armor" (Cervantes 1999b, pp. 32-33). This recitation of missing items closely echoes the first line, except that the last item, the galgo, has here been replaced by the armor. Also, the housekeeper inverts the order of the first three items in the sequence. The initial set $S_{0}=\{$ lance, shield, horse, $\operatorname{dog}\}$ has been replaced by $\mathrm{S}_{1}=$ \{horse, shield, lance, armor $\}$. The narrator shuffles the top three cards, deals "armor" underneath, and slips the dog card up his sleeve. Here is the point of erasure, the very moment when the dog is taken out of play.

What, then, is the armor that takes the place of the galgo? Introduced in the first chapter at the very point where Don Quixote puts his notion to become a knight errant into action, the armor is the most singular and distinctive item among Don Quixote's material possessions, the very object that defines his profile in the popular imagination, and it is an object granted a history of its own: 
"The first thing he did was polish up his great-grandfather's suit of armor, which for a century or so had been lying, thrown in a corner and forgotten, covered with mildew and quietly rusting away." (Cervantes 1999b, p. 15)

"Y lo primero que hizo fue limpiar unas armas que habian sido de sus bisabuelos, que, tomadas de orín y llenas de moho, luengos siglos había que estaban puestas y olvidadas en un rincón." (Cervantes 1999a)

Recall that the first line calls him "one of those gentlemen" ("un hidalgo de los de") (Cervantes 1999b, p. 13), an abstraction that suggests the presence of any number of similar gentlemen having the same possessions-a lance in the rack, ancient shield, old nag, and racing greyhound. What sets Don Quixote apart from those other hidalgos_-apart from the library—is this rusting suit of armor ("armas"). In the place of the unseen solitary galgo, which Beusterian observes to be "one of the first hunting dogs to be connected with purity of casta" (or "breed") (Beusterien 2010, p. 23), Don Quixote unveils his unusual armor. It's a curious coincidence to find that a suit of armor with a "metal headpiece that would cover just the top of his skull," i.e., a kippah-like skullcap, had been hidden away "for a century or so" (Cervantes 1999b, p. 15) (or, "for some centuries," "luengos siglos")—i.e., since well before the time of the 1492 Edict of Expulsion which forced Spain's Jews to choose between conversion or exile. This leads to an intriguing potential reading of the text that contrasts the pure-breed galgo with the Hebraized armor, thus commenting on the purity of blood, or "limpieze de sangre," of Don Quixote, or even of Cervantes himself. ${ }^{3}$

In Don Quixote's three-day absence, the housekeeper somehow notices that the "forgotten" armor is missing. This suggests that the armor had in fact not been forgotten, but rather conveniently ignored. The housekeeper never bothered to clean the armor at any point during her employment, but knew enough to include it in her inventory of missing items. She was aware of its existence, even as she tacitly participated in keeping the armor hidden and away from sight in a way completely unlike the lance in the rack and the ancient shield, those totemic items given prominence in the households of one of those typical hidalgos. Again, we discover echoes of the Jewish conversos forced to convert to Christianity, their hidden histories thrown in a corner, forgotten, and left to rust.

Regarding the galgo, the housekeeper says nothing. Since the housekeeper noticed the absence of Don Quixote's horse, it follows that she might have noticed if his dog had also disappeared to follow its master. We might explain her failure to mention the dog in one of four ways: First, the missing galgo may have fallen not under her care; given that it was a hunting dog, it would be the responsibility of the "boy for the fields and the market" (Cervantes 1999b, p. 13). Second, the dog may have returned ahead of its master, and so the housekeeper did not connect the dog's shorter absence with Don Quixote's absence. Three, the narrator, translator, or historian purposefully omitted the dog from the story. Fourth, the dog had stayed home. Whatever the explanation, at this very moment, the galgo is gone.

3 It remains an unresolved question as to whether Cervantes was of converso ancestry (i.e. a "convert" from Judaism to Christianity), with the argument generally divided between those who support the converso claim based on textual evidence within Cervantes' writings and those who reject the claim from a lack of supporting historical evidence. Lokos outlines the history of the argument (Lokos 1999), notably including the modern-day cultural resistance to the idea of a converso history for Cervantes' family. González Echevarría raises the converso question to dismiss it: "I am not convinced by the hypothesis, timidly advanced by [Manuel] Durán, that his teacher Americo Castro and other students of his proposed on very flimsy evidence, of a converso Cervantes - one, that is, whose purportedly Jewish background would have made him marginal. [... ] Castro's theories are, to my mind, too dependent on the racial hatreds and atrocities of the twentieth century to be applicable with little proof to the sixteenth and seventeenth centuries" (Echevarría 2005, p. 13). Durán weighs the lack of proof against Cervantes' overall tone as a writer: "A critical, ironic bent, plus an affinity for the ideas of Erasmus seem to point in the direction of a converso ancestry. The documentary proofs are lacking. Yet some of the best modern Hispanists, Americo Castro and Stephen Gilman among them, lean towards the idea that Cervantes came from a converso family" (Durán 2005, p. 32). McGaha surveys the literary and biographical evidence regarding Cervantes' heritage, including speculation as to the place and circumstances of Cervantes' birth, and although he remains skeptical of many of the claims based on the historical record, he nevertheless finds that "the most convincing evidence of Cervantes' converso background is the attitudes he displays in his work" (McGaha 2004, p. 174). To the body of textual evidence in favor of the converso designation, we may include the contrast between galgo and armor. 


\section{Hunting Dogs}

At this point, we can consider other galgo occurrences in the text for indications of anthropomorphic animal intelligence. The novel's second mention of galgo appears to be an insult:

"...and if indeed there's anything worthwhile missing, I'd blame it on its dog of an author, rather than on any deficiency in the subject itself." (Cervantes 1999b, p. 53)

"... y si algo bueno en ella faltare, para mí tengo que fue por culpa del galgo de su autor, antes que por falta del sujeto." (Cervantes 1999a, pt 1 chp. 9)

The translation "dog of an author" (Raffel), or even "hound of an author" (Ormsby), subsumes the specific galgo breed into a larger category. That "galgo" is an interdenominational insult seems a reasonable conclusion given that dog-related terms in the Spanish language carry negative linguistic connotations that Beusterien suggest were "inherited from the Semitic repulsion toward the dog" (Iser 2007, p. 99); and indeed, dog-related insults were commonplace on opposite shores of the Mediterranean. In "The Bagnios of Algiers," Cervantes' play inspired by his five-year captivity in Algiers, there are 20 occurrences of the word "perro" ("dog") and three occurrences of "galgo" (Cervantes 2017) (also translated in the English text as "dog" (Cervantes 2010))—all insults leveled at humans. Nevertheless, the breed specificity marks "galgo" as an odd insult, particularly given how it recalls the hidalgo's galgo.

The "galgo de su autor" comment arrives during a momentous narrative transition. After the first author runs out of source material and abandons the narrative in the middle of a climactic battle in Chapter 8, we then meet a second author in Chapter 9 who discovers a bundle of old notebooks in the Alcaná marketplace at Toledo. The second author has the notebooks translated, revealing the continuation of the history as recorded by the Arab historian Sidi Hamid Benengeli. This transfer of narrative control represents a key moment in what Haley calls the "supplementary story" (Haley 2005, p. 241) of Don Quijote:

"The characters in this corollary tale are all involved in the mechanics of telling and transmitting Don Quijote's story. Their adventures, not as violent as Don Quijote's but no less exciting for that, are the search for source materials in Manchegan archives, the creation of a continuous narrative from fragmentary and sometimes overlapping sources, the translation of the continuous narrative from Arabic to Castilian, the recasting of the translation and the publication of the revision, with intrusive commentary at every stage." (Haley 2005, p. 242)

Mancing writes: "Few issues in Cervantine scholarship have attracted more attention than the identification of the narrative voices in the novel and the clarification of relationships among them" (Mancing 2003, p. 118). Mancing identifies the presence of an editor who "undercuts his historian's authority and reliability by describing him as a lying dog of a Moor" (Mancing 1981, p. 66); and moreover, he identifies that editor as none other than the direct authorial presence of the historical Cervantes "who reconstructs the 'history' of Don Quijote, searches the archives of La Mancha, takes note of oral tradition, and pieces together a coherent story", acting as both the narrator of the fictional work starting in Chapter 1, as well as the segundo autor ("second author") introduced in Chapter 8 (Mancing 2003, pp. 129-30).

Haley calls this presence an "intermediary," the "shadowy figure who materializes at the end of chapter 8 to join the first author's fragment to the second author's contribution and appears again in the final chapter of part I to supply the concluding remarks" (Haley 2005, p. 244). In contrast to the first author's gullibility in relation to his unexplained sources, the editor displays relative sophistication; what the first author designates as "true" ("verdadera") history, the editor calls a "curious" ("curiosa") and "pleasant" ("apacible") history (Cervantes 1999b, p. 49). In doing so, the editor acts as librarian, recategorizing the book from history to fiction (Haley 1984, p. 179), and then the editor-much like the 
galgo—quickly disappears, a "persona invented expressly to tell the beginning of the story, [who] is discarded once the story is underway" (Haley 1984, p. 173).

Parr finds the intermediary narrator active throughout the entire text. The editor "obviously knows more and is therefore more powerful than either the first or second author-[and] can immediately be seen, retrospectively, to demote the first narrative voice, which we had innocently assumed to be the frame narrator, to subordinate or intradiegetic status." (Parr 2004, p. 127). In an extended analysis drawing on narratological concepts from Genette (1980) and Bal (2009), Parr designates this editorial voice as the "supernarrator" (Parr 1988, p. 11), offering evidence that the supernarrator remains distinct from the second narrator based on their respective attitudes toward Cidi Hamete. The second narrator "was censorious of the Moor" (Parr 1988, p. 16), while the supernarrator had a "more accommodating attitude toward the Moorish historian (Parr 1988, p. 17). Following Parr's analysis, based on the attitude expressed toward Cidi Hamete we can identify the voice behind "galgo de su autor" as the second narrator rather than the supernarrator.

If you're looking for talking dogs, "galgo de su autor" is a tantalizing clue. Stated plainly, what if we took the phrase "galgo de su autor" literally? The identification of the author as a galgo would signal the presence of a heretofore unheralded component of the novel's narrative apparatus. F.W. Locke, cited by Mancing, suggests that there was "an even more remote source for Cidi Hamete Benengali's manuscript" (Mancing 1981, p. 66). Along those lines, we can speculate that the galgo may have shadowed Don Quixote during some part of his adventures and then related those recollections through a human interlocutor-either the first narrator, Cidi Hamete Benegeli, or some other unseen source. Alas, if there was a talking dog in the archives, Cervantes does not reveal it.

That still leaves the question of why the second narrator used the unusual term "galgo" instead of any other term connoting "dog." Perhaps Cervantes was discarding the galgo card still hidden in his sleeve. In this analysis, Cervantes had taken the first steps in the opening chapter toward allowing a talking dog to follow Don Quixote and serve as his noble chronicler. Yet by the second sally, he had introduced a better interlocutor for Don Quixote's counterpart (Sancho Panza); and with the shift to the second narrator, he put into service a better chronicler (Sidi Hamete Benegali); and at some point during the composition of Don Quixote he conceived of a better vehicle for a talking-dog narrator (the Coloquio). With the housekeeper's sleight-of-hand, Cervantes removes the dog from contention as a sidekick, and with the second narrator's "galgo de su autor" comment, Cervantes bids an ironic farewell to the discarded idea of a talking-dog narrator.

Henceforth, the galgos in the novel have hunting-dog connotations: the galley slave compares himself to a galgo on a leash (Cervantes 1999b, p. 129, pt 1 chp. 22), much as a hunting dog would be kept on a leash prior to releasing its prey (see Figure 2); the Knight of the Grove observes that even the poorest squire has "a hack and couple of galgos and a fishing rod to amuse himself," to which Sancho Panza responds that he has galgos "enough and to spare in my town" (Cervantes 1999b, p. 423, pt 2 chp. 13); and Don Diego de Miranda describes his pursuits as "hunting and fishing, but I keep neither hawks nor galgos, nothing but a tame partridge or a bold ferret or two" (Cervantes 1999b, p. 439, pt 2 chp. 16). Finally, in the penultimate chapter of the Second Part of Don Quixote, we have the last appearance of galgos interrupted in the course of hunting a hare. Don Quixote takes these galgos to be a bad omen ("Malum signum!"), and Sancho, by this time knowing his master well enough to draw out the symbolic implications of Don Quixote's cryptic remark, provides a reassuring interpretation that casts the galgos as wicked magicians chasing a transformed Dulcinea (Cervantes 1999b, p. 738, pt 2 chp. 73). Yet Don Quixote is ultimately correct in his prophecy-Dulcinea does not come, and he soon dies. In the end, the galgos catch Don Quixote, dispelling his carefully constructed delusions. 


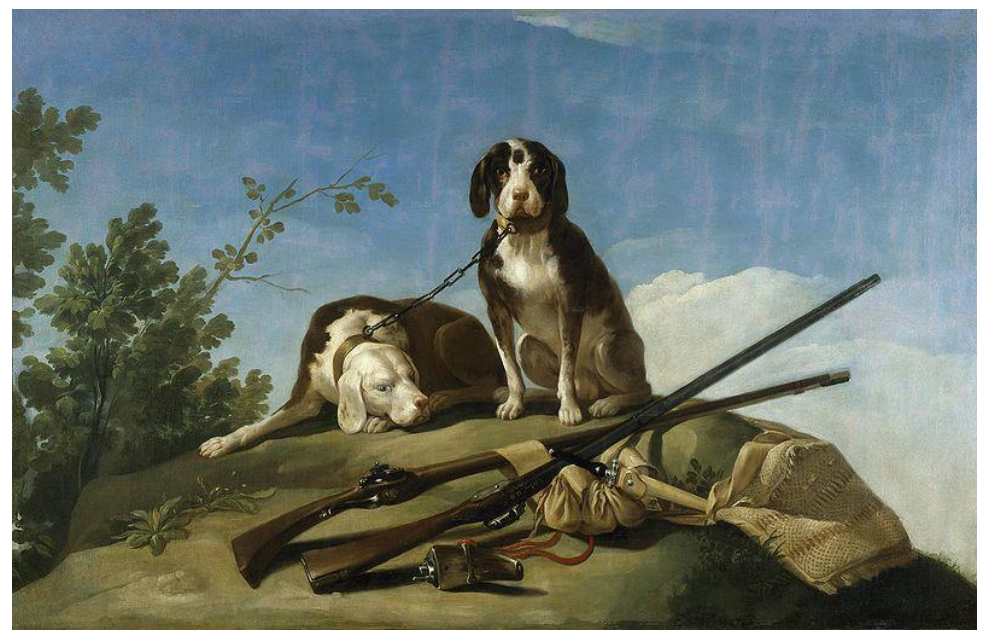

Figure 2. Francisco de Goya, Perros y útiles de caza o Perros en traílla (1775). Oil on canvas. $112 \times 174 \mathrm{~cm}$. Museo del Prado (Madrid, España) Public domain (Goya 1775).

With his reaction to the hunting dogs, we may reconsider Don Quixote's relation to his own galgo. At the beginning of the novel, he was introduced as a keen huntsman ("amigo de la caza") who then, by reading tales of chivalry, "almost forgot to keep up his hunting" ("olvidó casi de todo punto el ejercicio de la caza") (Cervantes 1999b, p. 13). At the start of Chapter 2, he leaves behind his previous life, including his dog and the exercise of hunting. By the end of the novel, he treats as deeply disturbing the appearance of galgos acting in the violent capacity of hunting dogs. With this personal transformation, we may discover a "critique of the hunt ... consonant with humanists who abhor the cruelty and excess of this aristocratic pastime" (Scham 2014, p. 108).

This emerging stance against the cruelty of hunting by dogs also extends to cruelty directed toward dogs. In the Prologue to Part II of Don Quijote, Cervantes relates two tales that he wishes the reader to personally convey to Avellaneda, a contemporary of Cervantes. Between the 1605 publication of Part I and the 1615 publication of Part II, Avellaneda stole Cervantes' characters to create his own derivative work, the so-called "false Quijote." In the first tale intended for Avellaneda, a madman traps a dog on the street, shoves a reed pipe into its hindquarters, and inflates the dog into the shape of a ball (see Figure 3). The madman addresses the people watching: "You think it's easy, your graces, swelling up a dog like that?" Cervantes echoes the question: "Do you think it's easy, your grace [i.e., Avellaneda], making a book?" (Cervantes 1999b, p. 361)

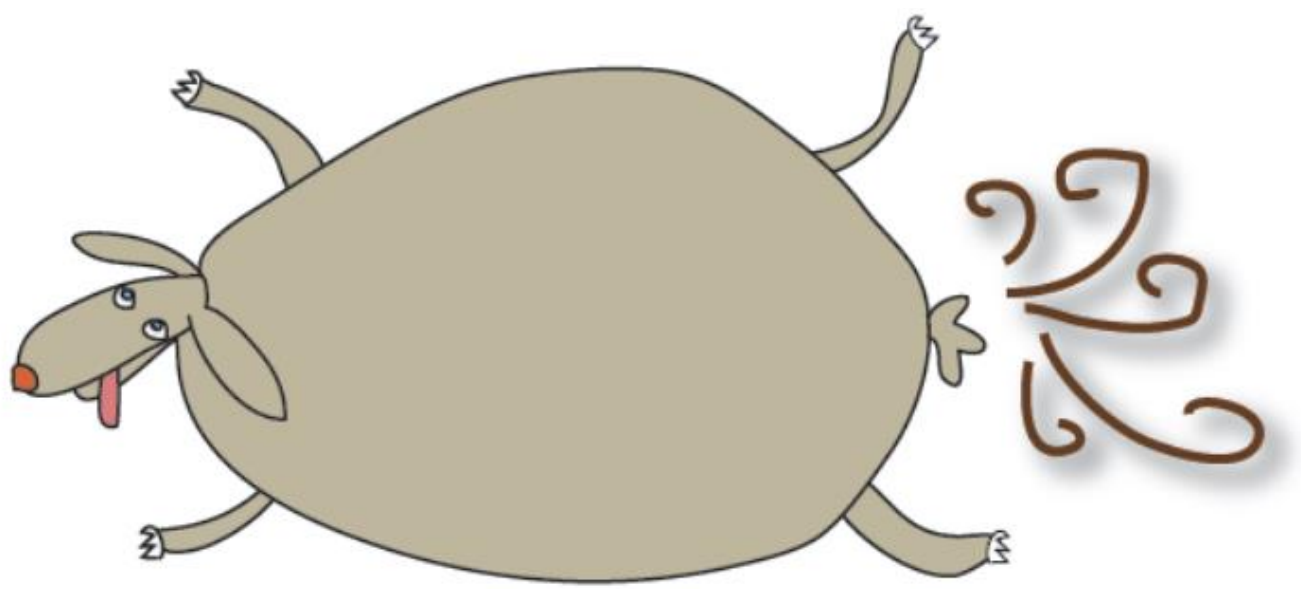

Figure 3. Tamara Schneider, Perro como una pelota. (c) 2017 Tamara Schneider. Used with permission. 
Beusterien interprets the inflated-dog anecdote: "Cervantes tells this story because he wants his reader to know that Avellaneda's sequel has taken his 'dog,' the first part of Don Quijote, and blown it up out of proportion, exaggerating the character of Quijote, for example, in unsightly ways" (Beusterien 2010, p. 102).

If the swollen dog represents Part I, a beaten dog represents Part II. In the second story, a madman who drops heavy rocks on dogs' heads is soundly beaten in return by the owner of one such dog, a whippet, or podenco, a smaller relative to the galgo. Cervantes delivers the moral: "Maybe the same fate [i.e., a severe beating] will befall our historian, and he won't drop his clever load into any more books, because when they're bad, books are even harder than stones" (Cervantes 1999b, p. 361). The second story also mentions briefly two other dog breeds: mastiffs, or alanos, and terriers, or gozques (see Figure 4). Fearing another beating, the madman mistakes all dogs for podencos, and thus refrains from dropping stones on any perro.

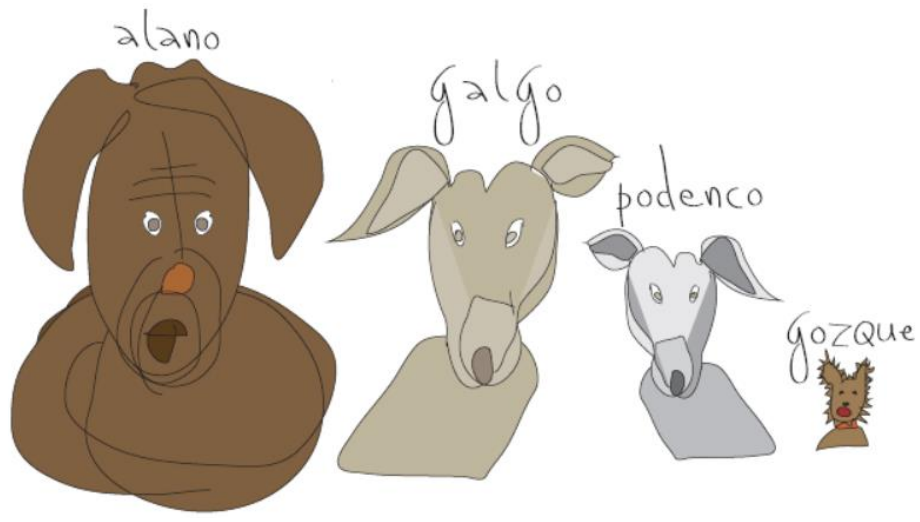

Figure 4. Tamara Schneider, Dog breeds in Don Quixote. (C) 2017 Tamara Schneider. Used with permission.

These sympathetic portrayals of the zoomorphic books-as-dogs representations of Don Quixote paint Cervantes as a defender of the canine species. Yet as the human companion to a sentient animal, the character of Don Quixote left much to be desired. Taking the lead of Haraway in taking dog-human relationships seriously (Haraway 2003), we should also consider the perspective of the abandoned galgo. The realistic post-history of Don Quixote's dog would not be that depicted in contemporary works by Estefanell (2004) and Carvajal (2005) imagining Don Quixote's galgos accompanying the knight-errant on new adventures. Instead, it would be more fitting to see the melancholy depiction of a morose, forlorn galgo wondering why its master curtailed their time together in favor of flipping through inky sheets of rolled wood pulp; lamenting the fate of being abandoned to the care of an indifferent housekeeper, Alonso's young niece, or the boy from the fields; and finally, dying as an unwanted dog in the overpopulated countryside. When Don Quixote finally returns home to die as Alonso Quijano, there is no Homeric reunion between a brave Odysseus and his faithful Argos. Don Quixote's last encounter with galgos is a malum signum.

\section{Conclusions}

Flores (1993) treats the galgo as a symbol of the past that had been left behind, and yet the past is not so easily repressed. Cervantes calls forth galgos at transitional moments in the novel with the switch from the first to the second author, and then upon the impending death of Don Quixote. In the prologue to Part II, Cervantes portrays both parts as dog-shaped books, with one of those dogs being a smaller relative of the galgo, the podenco. These are the indications that the galgo remained present in the mind of the author throughout the composition of the novel.

If we accept Cervantes as an improvisatory genius, then we must accept that earlier portions of Don Quixote were laden with infinite possibility. That is to say, if he started the novel with a galgo, there would have been many possibilities for him to play out the idea. We cannot assume that his 
initial intention was identical to his final expression a decade later. In its initial stages, the careful staging of the story left the way clear for an animal witness. That Cervantes chose a different path does not forestall the possibility that the earlier path had been strongly considered. We may excavate the traces of a talking-animal story within Don Quixote, reconstructing how through careful thought and experimentation Cervantes may have picked through and determined that the best option for Don Quixote was to trade the galgo for a suit of armor; and the best way forward for the idea of a talking-dog narrator was to come in the form of the Coloquio.

Cervantes' works have become objects of intense study by practitioners of narratology such as Parr and El Saffar. Following the lead of Beusterien, we can also anticipate further interest in Cervantes by scholars in the burgeoning field of animal studies. Now, with the emergence of animal narratology at the vibrant intersection of narratology and animal studies, we should hope for a resurgence of interest in Cervantes as a means of investigating the mechanisms by which animals are made to speak, and the ways in which humans speak on behalf of animals.

Lastly, I turn to "Las Meninas" (see Figure 5), the Velázquez painting so often referenced by Cervantes scholars including Gonzáles Echevarría (2015), Parr (2004), Ortuño (2012), Beusterien (2013), and others. The work, which so perfectly captures the interrelationships between creator, subject, and audience, has become a common visual entry point for grasping the logic of Don Quixote. Connolly describes "mystical ekphrasis" as "a mode of interpretation in which an image that occurs to the reader and that may have inspired the text, but for which there is no conclusive evidence, is used imaginatively to interpret the text" (Connolly 2017, p. 102). By that definition, the frequent reference to "Las Meninas," a work that chronologically could not possibly have inspired Cervantes, embodies an impossible variety of mystical ekphrasis. With animal narratology now being applied to Cervantes, "Las Meninas" has lost none of its impossibly mystical power, for there in the foreground of the painting, closest to the viewer and perfectly aligned with the corner of Velázquez's framed canvas on which he paints, we see a silent, trodden-upon figure patiently waiting with closed eyes-there, too, we find a dog.

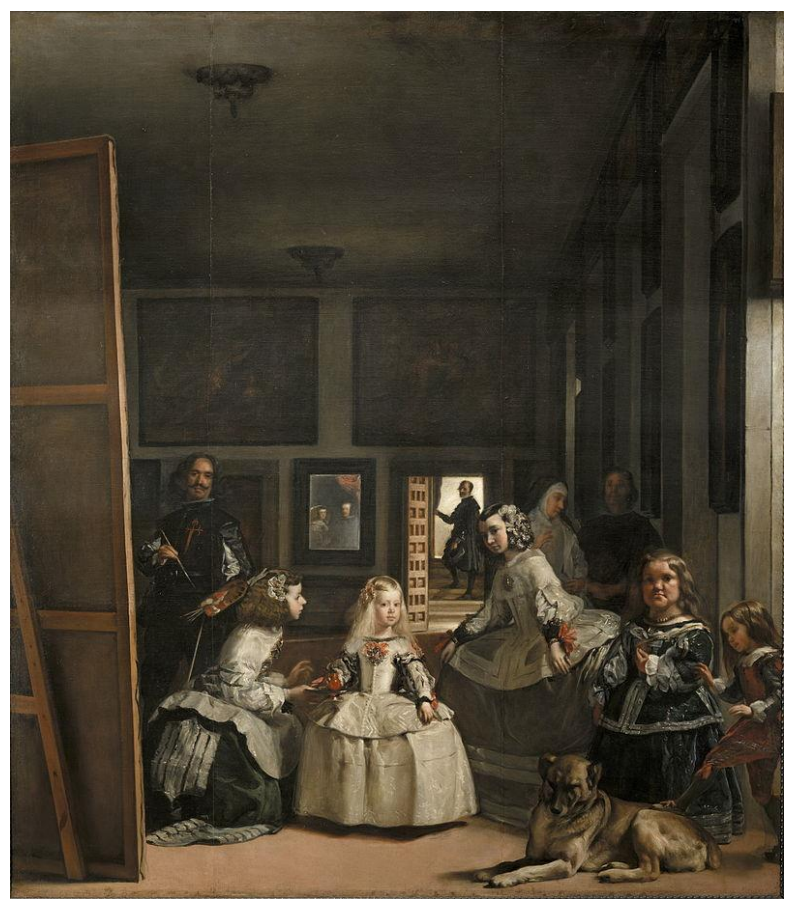

Figure 5. Diego Velázquez. Las meninas (1656), Galería online, Museo del Prado, Madrid, Spain. Public domain. (Velázquez 1656).

Conflicts of Interest: The author declares no conflict of interest. 


\section{References}

Bakhtin, Mikhail Mikhaĭlovich. 1981. The Dialogic Imagination: Four Essays. Edited by Michael Holquist, Translated by Caryl Emerson, and Michael Holquist. Austin: University of Texas Press.

Bal, Mieke. 2009. Narratology: Introduction to the Theory of Narrative, 3rd ed. Toronto: University of Toronto Press.

Bell, Aubrey Fitz Gerald. 1947. Cervantes. Norman: University of Oklahoma Press.

Beusterien, John. 2010. 'El nombre de podenco:' The Dog as Book in the Prologue of Part II of Don Quijote. Cervantes: Bulletin of the Cervantes Society of America 30: 99-112.

Beusterien, John. 2013. Canines in Cervantes and Velázquez: An Animal Studies Reading of Early Modern Spain. Abingdon, Oxfordshire and New York: Ashgate Publishing.

Carranza, Paul. 2003. Cipión, Berganza, and the Aesopic Tradition. Cervantes 23: 141-63.

Carvajal, Victor. 2005. El Galgo de Don Quijote. Santiago: Ediciones Sol y Luna Libros.

Cervantes, Miguel de. 1996. Eight Interludes. Dawn L. Smith, trans. and ed. London: J. M. Dent.

Cervantes, Miguel de. 1999a. Don Quijote. Salt Lake City: Project Gutenberg. Available online: http://www. gutenberg.org/ebooks/2000 (accessed on 3 February 2017).

Cervantes, Miguel de. 1999b. Don Quijote: A New Translation, Backgrounds and Contexts, Criticism. Translated by Burton Raffel, Edited by Diana de Armas Wilson. New York: W.W. Norton.

Cervantes, Miguel de. 1999c. Don Quixote. Translated by John Ormsby. Salt Lake City: Project Gutenberg. Available online: http:/ / www.gutenberg.org/ebooks/996 (accessed on 26 January 2017).

Cervantes, Miguel de. 2009. The Trials of Persiles and Sigismunda: A northern story. Translated by Celia Richmond Weller, and Clark A. Colahan. Indianapolis: Hackett.

Cervantes, Miguel de. 2010. The Bagnios of Algiers and the Great Sultana: Two Plays of Captivity. Barbara Fuchs, and Aaron J. Ilika, trans. and ed. Philadelphia: University of Pennsylvania Press.

Cervantes, Miguel de. 2016. Exemplary Novels. Translated by Edith Grossman. Edited by Roberto González Echevarría. New Haven: Yale University Press.

Cervantes, Miguel de. 2017. Los baños de Argel. Biblioteca Virtual Miguel de Cervantes. Available online: http:/ / www.cervantesvirtual.com/obra-visor/los-banos-de-argel--0/html/ (accessed on 19 March 2017).

Chekhov, Anton Pavlovich. 1976. Letter to Lazarev (Georgian) AS, November 1, 1889. In Chekhov AP Complete Works and Letters. Moscow: USSR Academy of Sciences. Available online: http:/ /chehov.niv.ru/chehov/ letters /1888-1889/letter-707.htm (accessed on 22 June 2017).

Connolly, Thomas C. 2017. Primitive Passions, Blinding Visions: Arthur Rimbaud's 'Mystique' and a Tradition of Mystical Ekphrasis. PMLA 132: 101-18. [CrossRef]

Covarrubias Horozco, Sebastián de. 1611. Tesoro de La Lengua Castellana O Española. Madrid: Luis Sanchez. Available online: http:/ / fondosdigitales.us.es/fondos/libros/765/16/tesoro-de-la-lengua-castellana-oespanola/ (accessed on 13 July 2017).

Durán, Manuel. 2005. Cervantes' Harassed and Vagabond Life. In Cervantes' Don Quixote: A Casebook. Edited by Roberto González Echevarría. New York: Oxford University Press.

Echevarría, Roberto González. 2005. Introduction. In Cervantes' Don Quixote: A Casebook. Edited by Roberto González Echevarría. New York: Oxford University Press.

Echevarría, Roberto González. 2015. Cervantes' Don Quixote. New Haven: Yale University Press.

Estefanell, Marcelo. 2004. El Retorno de Don Quijote Caballero de los Galgos. Buenos Aires: Ediciones Carolina.

Flores, Robert M. 1993. Don Quixote as a Genre of Genres. Romance Quarterly 40: 211-25. [CrossRef]

Genette, Gérard. 1980. Narrative Discourse: An Essay in Method. Translated by Jane E. Lewin. Ithaca: Cornell University Press.

Goya, Francisco de. 1775. Perros y útiles de caza o Perros en trailla. Oil on canvas. $112 \times 174 \mathrm{~cm}$. Museo del Prado (Madrid, España), 1775. Wikipedia. Available online: http:/ / commons.wikimedia.org/wiki/File: Perros_y_\%C3\%BAtiles_de_caza.jpg (accessed on 13 February 2017).

Greco, El. 1568. Adoration of the Magi (1568), Museo Soumaya, Mexico City. Public Domain. Wikipedia. Available online: https: / / commons.wikimedia.org/w /index.php?curid=35846297 (accessed on 25 June 2017).

Haley, George. 1984. The Narrator in Don Quixote: A Discarded Voice. In Estudios en honor a Ricardo Gullon. Lincoln: Society of Spanish and Spanish-America Studies.

Haley, George. 2005. The Narrator in Don Quijote: Maese Pedro's Puppet Show. In Cervantes' Don Quixote: A Casebook. Edited by Roberto González Echevarría. New York: Oxford University Press, pp. 241-64. 
Haraway, Donna. 2003. The Companion Species Manifesto. Chicago: Paradigm Press.

Iser, Wolfgang. 2007. The Reading Process: A Phenomenological Approach. In The Critical Tradition, 3rd ed. Edited by David H. Richter. Boston: Bedford/St. Martin's.

Johnson, Carroll B. 1993. Cervantes and the Unconscious. In Quixotic Desire: Psychoanalytic Perspectives on Cervantes. Edited by Ruth Anthony El Saffar and Diana de Armas Wilson. Ithaca: Cornell University Press.

Lokos, Ellen. 1999. The Politics of Identity and the Enigma of Cervantine Genealogy. In Cervantes and His Postmodern Constituencies. Edited by Anne J. Cruz and Carroll B. Johnson. New York: Garland Publishing.

Mancing, Howard. 1981. Cide Hamete Benengeli vs. Miguel de Cervantes: The Metafictional Dialectic of Don Quijote. Cervantes 1: 63-81.

Mancing, Howard. 2003. Cervantes as Narrator of Don Quijote. Cervantes 23: 117.

McGaha, Michael. 2004. Is There a Hidden Jewish Meaning in Don Quijote? Cervantes 24: 173-88.

Navarro, Gregorio Martínez. 2006. El galgo fantasma de Don Quijote. May 16. Available online: http://eljauregui.blogspot.com/2006/05/el-quijote-mordido-por-la-mala-lengua.html (accessed on 22 June 2017).

Ortuño, Marian. 2012. Reading Las Meninas: An Ekphrastic Approach to Teaching Don Quijote. Hispania 95: 681-97. [CrossRef]

Parr, James A. 1988. Don Quixote: An Anatomy of Subversive Discourse. Newark: Juan de la Cuesta.

Parr, James A. 2004. On Narration and Theory. Cervantes 24: 193-35.

Patrick, Brian D. 2008. Metalepsis and Paradoxical Narration in Don Quixote: A Reconsideration. Letras Hispanas 5: 116-32.

Pidal, Ramon Menéndez. 2005. The Genesis of Don Quixote. In Cervantes' Don Quixote: A Casebook. Edited by Roberto González Echevarría. New York: Oxford University Press.

Saffar, Ruth El. 1976. Cervantes: El Casamiento Engañoso and El Coloquio de Los Perros. London: Grant \& Cutler Ltd. Scham, Michael. 2014. Lector Ludens: The Representation of Games and Play in Cervantes. Toronto: University of Toronto.

Velázquez, Diego. Las meninas. 1656. Galería online, Museo del Prado., Public Domain, (Madrid, España), 1656. Wikipedia. Available online: https:/ / commons.wikimedia.org/w/index.php?curid=15474596 (accessed on 25 June 2017).

Wardropper, Bruce W. 1957. The Pertinence of El curioso impertinente. PMLA 72: 587-600. [CrossRef] Ziolkowski, Theodore. 1983. Varieties of Literary Thematics. Princeton: Princeton University Press.

(C) 2017 by the author. Licensee MDPI, Basel, Switzerland. This article is an open access article distributed under the terms and conditions of the Creative Commons Attribution (CC BY) license (http:/ / creativecommons.org/licenses/by/4.0/). 